\title{
The Role of Intention in Spirituality in Terms of Islamic Texts and Positive-oriented Psychology
}

\author{
Zahra Sharaf al-Din \\ Ph.D. Student of the Quran and Hadith Sciences of International Ferdowsi University of Mashhad, Iran \\ Email: zahra.sharafodin@gmail.com
}

\section{Mohammed Hassan Rostami}

Faculty Member and Assistant Professor of Quran and Hadith Sciences of Ferdowsi University of Mashhad, Iran Corresponding Author Email: rostami@um.ac.ir

\author{
Abolfazl Ghaffari \\ Faculty Member and Assistant Professor of Educational Sciences of Ferdowsi University of Mashhad, Iran \\ Email:ghaffar@um.ac.ir
}

\section{Doi:10.5901/mjss.2016.v7n3s2p15}

\section{Abstract}

\begin{abstract}
Spirituality and its relation to positive thinking and creating inner peace and satisfaction in humans is one of the most important topics in the field of Islam and psychology. The diversity in motivations and approaches and objectives in evaluating spirituality concept led to different interpretations in its fact and roots and its results. The aim of this study is to determine "the role and impact of intention in the realization of spirituality in Islamic texts and positive-oriented psychology". In this paper, at first we talk about the concept of intention and spirituality and their similarities in two vision and then differences of considered goals in intention and spirituality, their consequences in creating true peace were explained. Later it was determined that first, in comparing intention and spirituality in Islamic texts and positive-oriented psychology, good catches of divine pleasure and happiness of God as the highest and best purpose in absolute perfection defined in Islamic texts and the deepest and most influential components in reaching true peace and unique factor in the flexibility and resiliency of humans. And secondly, positive-oriented psychology in their evolutionary process does not necessarily need to benefit from the substantial knowledge in the field of ontological and anthropological principles. The method of this research is evidence-analysis.
\end{abstract}

Keywords: intention, spirituality, Islamic texts, positive-oriented psychology

\section{Introduction}

Mankind is always looking sustainable peace from the start and along the history, did everything to achieve this goal. That is why the understanding of life Secret and human reality are the most basic issues of wisdom and knowledge. And on the basis of different theories and anthropological assumptions about human reality, different ways were designed to achieve peace. But as human more and faster use these methods and strategies, goes further away from real peace. Seligman, the father of positive-oriented psychology, based on the World Health Organization findings, depression is the most costly disease and antidepressants drug industry is a multibillion-dollar industry in the world. He believes that the prevalence of depression among young people around the world is surprisingly high. According to some estimates, the prevalence of depression is 10 times more than fifty years ago, (Seligman, 2013).

On the one hand people seek satisfaction and inner peace, happiness and hope and freedom from suffering in life and on the other hand, the history of human civilization in recent centuries indicates that the scientific advances and industrial and social systems, especially in the west land, not only providing these demanding, but also increasing anxiety and human emptiness. Seligman considered modernity and what is wrongly called "welfare" as a main reason for reducing the amount of national happiness in various countries. (The same).

What is highlighted more than ever is lack of human wishes and goals conflict with practices and practical applications and his life style. To fill the lack that modern man has turned to spirituality. With this approach, positiveoriented psychology in recent years providing components to the happiness and well-being and relaxation of human and one of the most important and effective component is in positive thinking and mental health, spirituality and meaning to 
life. Positive psychologist to goodness found that having a higher purpose in life and superior performance, resulting in more dynamism, vitality, hope and success in human. But something that must be considered is whether what positive psychologist provided as spirituality and have high and superior purpose, can end the anxiety and confusion of man today?

This paper compares the belief in attaining God's satisfaction as the highest and best purpose and core of traditional spirituality in Islamic with spirituality and purposes and its characteristics in positive-oriented psychology, and the effects of the two views is discussed. Positive-oriented psychology, because there is no precise definition of sacred goals and transcendental knowledge infrastructure in the ontology and ethics, is faced with significant challenges. Including inefficient positive methodological knowledge on the spiritual basics as well as the diversity and abundance of material and spiritual goals that some are conflicting to each other and inconsistent in spiritual results.

\section{The Concept of Spirituality and Intention}

The word spirituality, forged as a spiritual and moral sense and spiritual being, attributed to the "meaning" against literal and true meaning, true, genuine, essential, absolute, esoteric and spiritual. The term is also known against the material, formal, appearance, and meaning only to the heart and the language is not in its interest (Dehkhoda, 1998, 2190/4).

Spirituality is created from a Latin word Spiritos meaning life or spiritual role "way of being" and "experience" with the awareness of a non-material dimension and detected values, determines it. These value is connected to others, itself, nature and life and to anything as extreme as the one referred to (West, 2014).

The word intention is taken from the Arabic word "Noy". Alnoy in Arabic word meaning palm kernel (Farahidi, 1410, vol. 1, p. 238). Word Noy in its current form, meaning the intention, determination, need, demand (the same. 8, p. 394). But why we call motivation and efficient cause in human as a intention, is that intention is formed in heart before doing anything and then show itself as a practical form. In fact, the thoughts that are in the heart and the mind of human is the core of the action that show itself as a cover for action, such as palm kernel works. So, the intention is motivation and the efficient cause that is formed in the human heart or mind and it is unseen and hidden in the human heart, so that the palm kernel is hidden in the palm (Hor Ameli quoted by Ahmad Faqih, 1996, p. 124). This so-called Islamic culture has the concept of the origin of the Qur'an, God in many verses reffered to the intention as its term meaning (Hashr 8, Ensan 8 and 9, Raad 22, Nisa, 38, al-mumtahina 1, and....).

\section{Difference of Intention and Attempting}

Intention is purely esoteric that comes from will, power and attempting of human. Attempting is a will to act, but the intention, in addition to the will and decision, is goal setting, on this basis, we can say: the owner of intention, has the face of goal and objectiveness in himself/herself. So, when someone is intended to do something, in fact, growing an attempting to do something purposeful in himself/herself.

From scholars view attempting to do something means a will to move or decision on doing an act and before doing an act, but the purpose of intention, is the purpose before doing an act and concomitant with action to the end of the procedure. Allameh says in the biography "And the intention to do the will of the heart compared to pay for it with progress be determined" (Helly, 1414, vol. 5, p. 328). Seyed Javad in Meftah Al-Karama, by Allameh Vazekri and first martyr narrates: "attempting before doing an act is a will not intention (Ameli, 1419, vol. 2, p. 275, First martyr, 1419, p. 80). So in terms of Islamic law, intended means in addition to the will and decision, it is determined purpose and bias of act. Intention of Muslim in their actions must be faithful to God and closer to his satisfaction and be cleared of any suspicion.

Category of narratives, know intention like act and sometimes better than that. As Imam Sadiq said: "intention like act" correctly, intention like action (Kleene, 1990, vol. 4, p. 56). The Holy Quran says: "The whole works on Shaklth Frbkm least Ahdy Sbyla Hu declared me" (Isra, 84) Say, everyone acts according to their character and your Lord guided is more aware of guided one.

In some traditions configuration is intended to be interpreted. Imam Sadiq said: "The intention is superior to action." He then recited the above verse, he said, adding that the purpose of the configuration is good (Kleene, 1990, vol. 2, p. 16). The formation of the structure and content of the human spirit as a result of heredity and upbringing and social culture comes to humans. From the perspective of psychology, the human figure synonymous with the word "character" is a set of behaviors and characteristics of mental and physical tomorrow and distinguishes him from others or external effects in humans. This interpretation is the interesting point that the good man gets up from his beliefs and to act in good shape and is a figure that is bound. So, sometimes good and sometimes it has interpreted to fulfill their superior operation 
is known. The Prophet said:

It is only applicable to good value and in fact is what the intent is for every human being (Gray, 1407, vol. 1). So the origin of intentions, beliefs and faith and Islamic culture, and this intention must be divine but of Rhgzrmrft and faith in God and the resurrection and the prophecy is not the result of voluntary work and faith in the human heart, which if achieved, can realize good provide divine and divine intentions with doing good deeds can guarantee human happiness. And here the role of faith in the realm of Islamic ethics and its integral relationship with the intentions reveals. "Teleological ethics in Islam, not only business school of moral virtues, but is seeking to please God in all internal and external affairs" (Tabatabai, 1417, vol. 1, p. 368).

\section{The Current Standard of Ethics from an Islamic Perspective}

Features moral system of Islam, according to Hassan agent (agent movement, 1409, vol. 1, p. 48) and the current faith in behaviours. Usually schools West's moral criteria to judge the value or worth of an act, the act and its results, which she attributed to subject and motivation and intent are subject raised (Popkin, Third Edition, p. 71). In other words, the current standard of judgment is only faith and motivation, intention, subject in this case is not involved, other than Kant (1369) subject to the motivation and intent of the act is moral criteria. But in Islam, the only measure of value, not current faith, but shall also be considered subjective. In many verses of the Quran "Mnva", Hassan agent and "Mlva Saleh", Hassan current, together cites and the behavior of both, he (Al-Nahl, 97, and Mary, age 96, 3 and so on). At first, the realization of faith in man, motivated by good deeds, and then do good deeds bring him happiness. In addition to these two factors, values and behavior of human actions on the basis of religion at another firm. (A) the quantity and quality of the act (of issuance of the act) and (b) the effects of the operation (became its ultimate) (gratuity, $108 \mathrm{II}, 104, \ldots$ ) With respect to the four factors that, when the current terms of the intent and motivation and its relation to the soul and spirit of doing something good but contracted works attributed to an individual or community or to the principle of good faith qualification is "obscene" and also considered the current and ultimate faith in cases where any two or one is not available, but Hassan agent and no motive has been made, act qualified as "good" or not current with current good agent is the final act but on the way is not acceptable as it in good faith, and Need help earn God's pleasure, but it can be done in a manner that would need to be humiliated (Hor amly, 1409, vol. 8, p. 304).

\subsection{Ethics and Positive-oriented Psychology}

West says: "For many people, the concept of spirituality is closely related to moral values. Elkins et al (1988) on the relationship between moral and spiritual growth, ie changes in the value of spiritual experience, focus and seems to be this notion, the best definition of spiritual being "(2014, p. 26). It must be said clearly in positive psychology to ethics issues not addressed but noted that the direct impact on the moral component of optimism, hope to improve their work. For example, as originality in the sense of honesty and integrity, one of the favorite philosophers and theologians and Islamic morality is one of the principles of positive psychology have been given today. Harter (2002) defines authenticity "of personal experiences, thoughts, feelings, needs, desires, preferences or opinions. . . . . A person based on his true, it acts "(p. 382) Seligman believes that" if high school business will be the economic consequences of greed and short-term gains temporary stay, have students from the moral sphere more widely and to Due to the longer-term benefits of their choice. " (2013, p. 276) the questionnaire practical value capabilities secretary (Peterson and Seligman, 2004), integrity (honesty, integrity) to the right as far right as if expressing themselves so honestly and doing things in a manner heartfelt presentation not, accept responsibility for your feelings and actions, have been described (Mgyar-Moi, 2012). As well as increased reliability, increased communication, creativity, innovation, creativity, performance and maintenance staff commitment, originality of work and benefits enumerated (Peace, 2000). The lack of originality mutually negative consequences of unethical behavior and emotional stress of the times. Gibbs, social and moral development in the social and behavioral sciences and processing led to the emergence of psychological theories to develop beneficial social behavior knows (Lopez, 2009). Because of the cultural, social and religious psychologists are facing, many of them may have a moral nature, and also due to the impact undeniable moral component in optimal performance, resulting in positive psychology focuses on moral issues is. Although a clear definition of positive psychology, there is a moral act.

\subsection{Spirituality in positive-oriented psychology}

One of the important components of Positive Psychology, Spirituality means sacred belief in the goal over and above its favorable impact on performance and well-being is positive thinking. Snyder, happiness, perfection and other forms of 
positive health as the main focus of positive psychology knows the significance of all of them is inseparable addition, meaningful life itself is a positive result is sublime (Snyder, Lopez, 2002). The term usually used to describe spiritual experience extraordinary moments for communication, and special quality near the man used "(West, 2014, p. 11). Hill (2000) conducted a comprehensive definition of spirituality have provided "feelings, thoughts and experiences arising from the recognition of a sacred creature." The term "recognition" to the effort to understand, speak, and then make the change worth noting apartments available so-called "sacred" to understand a divine being, and the divine, or the final by one point (Luthans, 2013, p. 183). "People are looking for meaning and purpose in life inevitably are. A "meaningful life" means what you think of "their" bigger and more important, in and serve you, and people all positive social institutions created to enable this. "(Seligman, 2013 p. 12). "Those who are successful targeted activities that will link them with the larger goals what they say it is life with meaning" (Rashid, 2008, p. 198).

Ryff \& Singer (1998), the purpose of life in fact, define the features of positive mental health, you know. Pargament (2007) stating that the potential capacity of human beings to search for the sacred in life are born, conclude that the search for the sacred is a unique feature of human motivation. And should be considered teleology sentence (Johansen, 2012).

Frankel (1978), a psychiatrist, existentialism that its therapeutic approach "Logotherapy" named, said: "The need for meaning, most human motivation and a fact in human life and without faith it is impossible to live more safely that "(Frankel, 2011, p. 146). Some psychologists have spoken of the profound relationship of religion with spirituality. Pargament says: "We prefer religion to classical, broadly defined as a personal dimension inherent to the various objectives, are both material and spiritual. A key function of the unique spirituality and religion show "(1999, p. 12).

According to Zinnbauer's report (1997) Empirical studies show that most people want their religious and spiritual identify. Shafranske inevitable because of the relationship of religion and spirituality, believes that "psychologists should pay attention to spirituality. Because spirituality is a "cultural fact" and that most Americans believe in God (95\%) and believe that praying to God and prayer can be approached (86\%) feel that religion is important to them or very It is important "(Shafranskh, Maloney, 1996, S586-561). But religion and spirituality are not the same concept and the spiritual man is not necessarily religious. Zynbayr empirical research shows the difference between spirituality and religion structure (the same). The psychology of religion, traditionally, do not distinguish between these structures. (Wolff, 1998) definitions of spirituality is the best man (Twerski, 1998), trying to reach the existential meaning (Doyle, 1992), to the noble man (Mauritzen, 1988) is divided. Even each of these definitions rich alone cannot satisfy all. For defining the relationship between spirituality and religiosity must be specified (Wolf, 1998, according to Snyder, Lopez, 2002, p. 247 and 248).

"In spite of the increasing emphasis of scientists on the spiritual dimension of human development, and human growth and development is a meaningful movement (Erikson, 1963; Rogers, 1961, Vaughn, 1993), yet a coherent definition involving the spiritual integrity is not provided "(West, 1393, p. 11 and 10).

\section{Compare the Effects of Spirituality in Islamic Texts and Positive-oriented Psychology}

Spirituality in Islamic texts and positive-oriented psychology have overlap in the following cases:

1. The existence of the ultimate goal: the goal of having higher and higher performance

2. Spiritual, metaphysical dimension: the superior purpose is experienced as distinguished God or superior or metaphysical dimension, and gives sanctity to life.

3. The meaning and purpose in life: to fill the vacuum of existence by meaningful life and rediscover the value, meaning and purpose in creation and that human being understands in this way that he/she is part of something bigger and broader than feeling about himself/herself.

4. The lack of importance to material values: find ultimate satisfaction and comfort in spiritual values rather than material things.

5. Create positive thinking: real spiritualism can create positive change in the attitude and behavior of the aspects of being and way of living and draw a better world in the mind and tends to realize those aspirations.

6. Resiliency and flexibility: resilience is capacity to return from stable and continuous difficulty and the ability to repair itself. With the spiritual, the human capacity can take him triumphantly from adverse events and despite exposure to severe stress, improve his/her social, academic and career competence.

7. Have a mission in life: spiritual person has a sense of duty and obligation and responsibility towards himself/herself, society and nature.

8. Altruism: sympathize with the suffering of others, having a sense of social justice and cooperation with all parties. 
Spirituality differences in Islamic texts and positive-oriented psychology, in terms of principles, examples, practices and implications is reviewable.

\subsection{The difference in the principles and fundamentals}

Positive Psychology speaks of spirituality and the ultimate goal, but the theoretical background and principles expressed belief in the ultimate goal is neglected. A spiritual man is that, first of all, should recognize its truth and achieving realistic understanding of themselves, but by rational knowledge, philosophy and revelation of self and the world is not possible. Although some psychologists have references to it (Mosak and Dreikurs, 1977), but still in positive psychology, types of spirituality, based on principles and not differentiate its infrastructure and the most supreme goal is not defined.

The spirituality of Islamic point of view, based on certain principles and without foundation based on this theoretical framework, essentially from spiritual truth, will be empty. In Islamic literature, based on ontological issues, certain elements of true spirituality, is expressed as follows:

- Rationality (Sore ص. 29).

- Belief in the spiritual dimension of existence (Isra, 85).

- Belief in Almighty, Powerful God with all perfection that has distinguished existence and sublime of the possible (human, 30 and Baghare, 20).

- Belief in the in a meaningful and world and purposefulness of creation and human being creation (Anbiya, 16).

- $\quad$ Belief in human freedom and the possibility of his/her risen or fallen (al-Kahf, 29).

- Belief in influence of simple actions on the formation of the inner truth of human being and the interplay of outward and inward (Muhammad, 30 Ankabot, 45).

- $\quad$ Belief in the Resurrection and the Hereafter (al-Kahf, 21).

From an Islamic perspective, the beliefs and intimate and necessary relation with the intention of winning the love of God, in all its actions. In fact, the "good" true symbol of spirituality and belief in this is the ultimate goal. Convinced that their human and transcendent being the highest and most sacred does and in every moment of life to a depth of penetration, and her life to the ideal hard to overcome. Man can speak directly with him and trusting in Him and seek His help. With this goal in just temporary moments of sensory experience or mystical, not sure, but they are constantly in the presence of Almighty sense that is absent of any time and place. And with this belief, the moments of his life will be purposeful, spiritual and worship.

\subsection{The difference in meanings}

The goal is to be an intellectual in intent and Islamic spirituality, sacred, transcendent, absolute gentleman and has all the virtues of knowledge, wisdom, power, life, and mercy. . . . . . And creator (Zumar, 62) and paste absolutism (Raad, 16) and the rich and the absolute need (Fater, 15) is associated with him is not required by the neck veins are closer to humans $(G h, 16)$. While the purpose of the objective of Positive Psychology, any of the material and spiritual superior performance than is desired. Even when the target is stressed by some psychologists, a distinct and distinguished sacred cannot be anything spiritual.

Professor Brian Thorne, adviser, client-centered, God's highest goal, the success of the action, heals, and gives integrity, states (West, 1393 p. 75). Adler (1956) any move that ensures public welfare into consideration as the ultimate goal and it's fabulous. On the other hand, sexual intercourse can be used as a spiritual goal. West says, "In our postmodern world, eternal unchanging truth as a phenomenon, is facing many challenges. In the context of a sexual relationship can exist deep spiritual sense, the words of Carl Rogers: "When in peak physical (sexual) will take place, probably to draw up their own spirituality." The reverse is also true, because everything can be part of a psycho-spiritual unity "(ibid, p. 181). Yang (1998) to express spiritual self knows me himself that live in close contact for their "premiere" tries. One of the major criticisms of the treatment of humanism or, in fact, New Age spirituality, focusing on individuality and that is a form of narcissism. While Perry and Jones (1996) on the Buddhist approach for therapists increased emphasis (ibid 73). "Eastern spiritual traditions, meditation leads to enlightenment is the ultimate goal, you know" (tart and Daikman, 1991, p. 29). Spirituality different definitions and perspectives of psychologists in this area is very diverse.

\subsection{Differences in practices}

Spiritual practices and solutions in positive psychology, first of diversity, charm and great and small Secondly, tangible and operational. Such as relaxation and meditation or meditation in various ways (Carr, 2012) New Age spiritual practices 
(telepathy and...), Shamanism or religious healing, practices Buddhism, Zen method, preaching spiritual (West, 2014) type activities friendly (Mgyar-Moi, 2012), and the like.

But in Islamic texts, although the most effective and general spirituality way, detailed descriptions and operating characteristics not addressed details of these practices, for example, stipulation practices, meditation, expostulation calculation and self-cultivation and self-purification as valuable solutions Generally considerable emphasis on Islamic spirituality recommendations (Makarem Shirazi, 1998) and many mystics, scholars and true believers of these methods, however, have sufficient interest to form part of the process of action and strategies regarding Details of the purpose and the spiritual journey to the destination, as well as the quantity and quality of performance analysis and not on dealing with barriers, particularly in complexity and application conflicts with the sensuality and the devil, in detail, designing has not been set. However, as David Hay said: "Anatomy of a religious experience, is difficult" (1982, p. 152).

\subsection{Differences in effects and consequences}

The effects and benefits of Islamic spirituality based on the belief that honest intentions in everything, broader, deeper and more stable than spirituality in positive psychology whose results it is temporary. West speaks of the mystery whose resolution is not easy, because in some moments of life are spiritual experience special and sometimes this is not so and this is, as reasons for the lack of consistency is the spiritual status (1933, P18).

\section{The Consequences of Believe in Intention in Islamic Text}

\subsection{Cohesion and absolute harmony and imparted in the life style is one of the consequences of intention.}

Believer, all your actions from the beginning of determination and heart contract, with the aim of pleasing God puts a clear goal, at least for part of the definition is comprehensive and in fact all part of the overall goals and actions in life and in all aspects of spiritual and material, under the umbrella of this great and sacred does. And in fact the believer, in the context of a coherent whole with significant harmony with oneself, others and the universe to life is the supreme goal of the integration is one of the unique features is believed to be good. God says in the Quran: Oh, Prophet say: In fact, my prayer and worship, my life and my death are for Allah, Lord of the worlds he does not share the work I have been commanded and I am the first Muslim" (Anaam, 162 and 163).

\subsection{Rationality and real and stable peace is one of the consequences of believe in intention.}

It was not because God commands real benefits and disadvantages in accordance with reason, not unreal, legislation, and regulations imposed by someone, that wisdom is the most thorough knowledge of human nature and the way his collection to have happiness and perfection. The harmony of reason and religion, the science of jurisprudence, is accompanied rule and states that "our entire sentence minded ruling al-Shara" Whatever the reason for that ruling, the judge also ruled on it. The reason is one of the fundamental principles of Islamic law (Mozaffar, vol. 1, p. 217). The rational principles of good and evil is also proved that obedience to the commandments of God's wisdom (Mohaghegh Damad, 1406, vol. 4, p. 18). On the other hand canon law, in accordance with the proper nature and human creation is sweet. The result is that religion and reason together and capabilities and the judge ruled that there really is contrary to nature, therefore, freshened inherent good coordination and action, in this world and hereafter Real satisfaction.

If God says in the Qur'an: "Whispering Allah name brings peace to hearts" (Raad, verse 28) only a remembrance of Allah brings peace to hearts.

\subsection{Flexibility and extraordinary resiliency are the key features of act based on intention, although spirituality in positive} psychology also provides positive resistance

In his book of psychological capital is as follows: "Based on the positive impact, one of the most important characteristics of spirituality, effective resistance is hard" (Luthans, 2013, p. 185). In the same book, on the role of values in flexibility, writes: "the values and ideas to help people who stood up against problems and horrendous conditions of the present and the future they can expect smoother they bind "(ibid, p. 115).

Snyder and Lopez said: "proportion of positive psychology emphasizes the fact that the degree of desire for a meaningful life in the fact that significantly reduces pain. Even in the absence of pain and trauma, there is no meaning in life man uses the least amount of their abilities. "(2002, p. 616). Pargament (1997) come to worship and religious and 
God help relieve depression and reducing the suicide rate, in the face of people's life stress (job, 2006). Research on the role of values and beliefs to maintain significant flexibility when faced with severe physical and psychological challenges support (Holly Dee and Mick Pearson, 1997).

The positive psychology talks about the effect of human values and beliefs on flexibility promotion. This is also confirmed by Islamic texts.

Researchers at the Empirical studies have shown that people with negative life events in a more charitable interpretation of their religious framework, generally better adapted to the crisis of his life experience. For example, when Jenkins and Paragmnt (1988) of cancer patients in the control of disease upon them, asked, referring to God's control, with individuals report higher self-esteem and better reporting of Nurses of their adaptation, linked (Mikel, Pargmnt, Brent, and hip 1998, according to Snyder, Lopez, 2002, p 654).

It must be said intention is a great value to any small or great material and spiritual, through true faith, worship and rewarded and considered. So the intention is honest entrepreneurs and their value is derived original values and beliefs. Beliefs such as:

\subsubsection{Oneself "act responsibly and do duties", is worship without achieving the desired result, and makes meaningful all acts of human}

One of the important factors of psychological disorders and disappointment in life, lack of delivery to the desired result and purpose in life and the belief that only the practice leads to the desired result, business is valued, suffering, failures of life and loss of work and effort in the time, life and property, hundredfold and is unbearable.

But in Islamic culture, the obligation, the law is holy, and because of the context of legislative affairs genetic exported, Islam, the perfectly rational, and reason dictates that duty, and the current result is contagious.

Human so as to achieve the result would acts based on the duty, if the result is not desirable, not only don't feel regret, loss, anxiety and despair, but also thanks $\mathrm{G}$ that doing his duty that is nothing but religious and wisdom. Because "do the duty" per se limit is worship and rewarded considered well. And such a belief, could bring full of spiritual joy and peace of mind to faithful person, and suffering setbacks have restored and hopefully provides a new resolution for other action.

The Holy Quran says: "Do you expected something except these two goodness? (Tobe, 52). From religious view good and disaster are both good, because if good, is good for is to win the trophy in the world and a great reward in the hereafter, and if disaster is good for is failure and death and human suffering that would be pleasing to God and leads to eternal reward, so both are good "(Tabatabai, 1417, vol. 9, p. 307). So man theistic God does not think anything except doing his/her duties and after using their best, does not worry about failure.

\subsubsection{Trust in God Almighty is energizing and relaxing.}

John Hick says: "The meaning of life is that even in the darkest moments of life that is full of pain and sorrow, can be trust and confidence at the height of the heart" (Hike, 2000, S269-286).

In the Islamic vision, trust, means a man knew only God as the power of infinite point for reliance and trust him and he considered his only real backup and in front of him does not rely on any other available because no one except Allah, worthy Trust. However, trust in God does not mean leaving your effort and planning and activities and disclaimer, but also faithful man who is using all the possibilities for success and tries to achieve the desired goals and at the same time believe in the fact that God is the cause and all works is in his hand, and things to he who accepts it, it would certainly be achieved, however, is difficult and unlikely.

One of the crucial tasks of human anxiety that has impact on human mental balance or imbalance. Cohen is a relationship between risk potential adverse outcomes and concludes that the potential risk factors (vulnerability factors) may be in the form of several successive severely adverse events, and the likelihood of adverse outcomes increase (Cohen et al. 1996).

To cope with the adverse effects of risk factors, trust gives courage to man to do the job. In this context the Holy Quran says: "So when you decide to do something now trust in God because God loves trustees" (Al Imran, 159). Imam Ali said: "Whoever puts his trust in God difficulties will be easy for him, and tools are provided to him" (Amadi, 1410, vol. 5 , p. 425). Faithful persons when felt the situation is out of their power and control with trust in the power of God and the relationship between themselves and God to make sure that god makes things easy for them and God will not abandon them in a pinch of hardships and difficulties. This believe gives an extraordinary power to faithful persons and obstacle overcome loneliness, weakness and helplessness. And on the other hand faithful person in the interpretation of 
phenomena, always have, wise, tender and good God, and if the incident would occur with a mystical view it as good as it looked, and passed with peace of blind events and Passion.

\subsubsection{Believe in the absolute and infinite knowledge of God}

Knowing endless knowledge of God and the certainty that God created human beings than all the heavens and the earth, and to all people covert and overt actions, partial and general science, and even the inner beliefs and intentions on how and what the heart and human life, the secret is governed and informed (Taghabun, verse 4).

Believe in infinite knowledge of God is bringing peace in following items:

A. When an innocent man, will be addressed guilty and sinful innocently. In this context, believe in God's knowledge of all things secretly and openly, and with faith that God would comfort him with hope for the future, will be waiting to get out of this situation.

B. lack of appreciation and ignore someone suffering great effort to achieve the goal of sustained, very annoying, but faith in God's knowledge of all the moments of human life, prevent frustration, frustrated, ineffectiveness actions and regret over the loss of his life, opportunities and investments in the past because they believe that God will reward everything from the smallest to the largest, even if a bit too good to be, it will reward (Zelzeleh, 7).

C. In the absence of good faith and honest work to do, but because of ignorance about the correct procedures and guidelines for action, the outcome is not favorable. Faith in God is aware of his good intentions positive and important point of his action, causes of action not disappointed again and make up for it with trust in God, to act.

D. In the face of a disaster that life is fragile for some wonderful people, believing that God's wisdom and interest in science and encompasses all things, good and positive interpretation of all events, ugly and beautiful life creates a positive metaphysical interpretation of every event, the fragility and despair, reduces (Baqara, 216). One way to maintain a belief in a just God and merciful in dealing with trauma and loss, taking a spiritual purpose, pleasant and expanded beyond a negative event. This way, a form of renewable context in which the crisis of the moral sense, or even transformed into opportunities for growth (Snyder, Lopez, 2002). Hazrat Zeinab (S), after the Battle of Karbala, where more than twenty martyrs, nephews and cousins and brothers and their children were being held, in response ibn Ziyad asked: "How do you see the work of God with brothers and relatives "said a sentence that represents the pinnacle of theism, and mental strength of his optimism that the faithful, true spiritual meaning and sweetness do not understand it," But what I saw beautiful "I did not see the beauty (Ibn Tavoos, p. 160).

E. The part of the frustration and bitterness of a man not related to his/her actions and it's not a a result of his/her actions. Bearing difficulties and hardship that their man is not guilty and not guilty, is very painful. But the belief that God is the truth of science and non-interference and unwanted incident man knows and believes that God's hand in front of the pain and suffering in the world or in the Hereafter, a gift to the man suffered gives the greater his suffering and through suffering that he has suffered, the compensation. It is very soothing (Heli, 1379, p. 137 and 138).

\subsubsection{With the intention of pleasing God, Allah, guide the action and bless it.}

Honest intentions, limit per se is a cause of causes. That is good, apart from the causes and perpetrators act itself plays an important role in guiding action towards the desired goal. "The intention is good, due to the mean" (Amadi, 1410, vol. 3 , p. 367). With the conclusion in good faith based on the real in the human heart, operates under the auspices and guidance of the scope and extent of divine intervention in his own benefit and be blessed. Believers who do good deeds for God's blessing and the blessing of the material and the spiritual.

Imam Sadiq (A) in the interpretation of the verse" To test you is best in deed "he said meaning is not that high but the purpose of your action is that you act right, and act right and good that the fear of God is true (Majlesi, 1999, vol. 2, p. 13). Amelie Javadi He says: "One if the current good way should be close to Allah, His grace is under seal, then the kingdom of God on his property and runs with the preservation of natural causes All aspects of causality, the righteous brings blessings to people or it takes person because God "first cause and the cause of causes" success is competence and events led them to adapt If man did not deserve this success brings and also not between him and world events "(2010, vol 10, p 648).

Imam Ali (A) said: "If everyone has a good intention, success would help them." (Nahjoalbalaghe, 2000, Sermon 
481).

Imam Sadiq (A) said: "Allah would help servants for their intention, whoever has a good intention God's assistance will be completed about his/her, and whoever has a weak intention God's help would be equally weak "(Majlesi, 1999, vol. 2, p. 11).

6. With Honest intentions, God compensates for the decline in the quantity and quality of the act.

Motahari said: "There is a different logic in Quran that is very strange and subtle and excellent," "(Shura, 23) that if we do well, and beautiful we will increase the beautifulness of the work, we cry and we pay. Once placed in the path of creation and the love of God is this. What you do in the divine, many flaws and shortcomings is that you will, but God's grace and mercy that eliminates the disadvantages and shortcomings and ugliness destroys your act and become a beauty. God's good work beautician Gary covered their evil deeds and bring good stead. . . . All this interest is that people around the world learn the guiding light that is turned on, the light of faith and the power of miracles and all of the original creation "(2000 Vol.4 p 139).

God Almighty nice addition to the quality of work, with grace and bounty also adds: "As God is better than what they used to do, to reward them and add to them of His grace" (light, 38). Fakhr Razi in the interpretation of the verse says: "First, the purpose of the" best actions" is all that is good. Second: God reward every single action seven to ten times "(1420, vol 24, p 398). Imam Sadiq said: "a person wanted to do a good action, after the work done, and if didn't do it, God would record a good act for his/her good intention. And if it did, he writes for him/her ten good "(Hor Amely, 2001, p. 3

\subsubsection{Intention is effective factor of growing and developing the aliment in life}

Aliment in the life of the most important issues that sometimes all it takes is human life. Which have much larger purpose in our lives is the goal of human life is placed. Imam Ali (AS) in such a key position to determine the provision of life and sustenance to our lives is not a toy. He said: "My son, your world as much for you, destined to amend" (Nahjolbalaghe, 2000, letter 31). The provisions true provision that God has for every human being ordained and it would save him the medications with the intention of honest and good deeds, and without concern achieved because God provided it has guaranteed (Isra, 30 and 31), not what with sin and greed, gain eternal happiness and be destroyed. God says: "He who does not fear God, God will give to him and to his opening where I do not believe it will one day" (Talagh, 2). Imam Sadiq (A) said: "Whoever makes good their intentions, the high aliments" (Kleene, 1990, vol. 3, p. 165). The Almighty God also says: "Everyone who refuse to worship me, would has a hard life" (HA, 124).

In this era, a clear example of "living stingy", the plight of the cultural, social, due to the susceptibility of capitalism, prosperity and attachment material is in the West, a world that is home to original and modern psychology.

Great material prosperity, rise to issues such as the decline of traditional values of community, kinship systems failure, moral licentiousness, alienation, sexual immorality, abortion, homosexuality, anthropocentrism, family destruction, environmental degradation, depletion and reduction of the risk of nuclear war and so such as that due to the inherent nature of these communities. Therefore, Imam Ali (A) said: "If the intention is corrupt, evil and trouble comes." (Nahjolblaghe, 2000, sermon 19).

Philip Cushman (1990) says, "Our environment is kind of forming the "self" of a person that fundamentally is facing the lack of community, tradition and common sense. Then, this empty self must be saturated by food, consumer products, celebrity's life, and media. To deal with a growing sense of alienation and fragmentation in the new era"(West, 2014, p. 83).

So the believer and the vision for the world is not more, less prosperity, unity and resurrection and earn a living without God's sake do not ask. Because according to material things matter, because of the heterogeneity of the divine creation and divine nature and the human spirit, misleading, anxiety and very harmful.

\section{Spirituality in the Psychological Literature}

Common spirituality in the West (the origin of positive psychology) diverse spirituality, world-oriented, and experimental sensory and cognitive impairments and a gain of more than ecstasy and escape from reality and the handling of problems in life, and sometimes a combination of rituals and religions there are significant discrepancies in the foundations. In this spirit, the ultimate goal and sacred, is not necessarily non-material or fixed and distinguished. Deny God distinguished and belief in God and acceptance of all religious pluralism and, above all, the lack of obvious bug's epistemology of modern spirituality.

Spirituality is not possible without spiritual interpretation of the truth of human and existence. Incompatible goals of 
those who are seeking spirituality and the lack of a comprehensive approach to different aspects of human and extremes in various fields, witness the failure of human reason in the interpretation of human nature and existence that is due to interrupted communication with the source of Revelation.

Remove the transcendent dimension of life, modern humans, causes psychological problems today is human, but to treat the pain, to practice meditation, oriental medicine, natural foods, yoga, psychological novel, mysticism affected by drugs, dance rain Native America, meditative Zen Buddhist, Quaker silence, as a kind of sacred, turned. All these things, to provide a temporary relaxation away from the troubles and suffering in the world. Is this diverse forms of spirituality, to the fundamental questions of today, the truth of human existence and its purpose, represents part of the answer?

Growth and rise toward the transcendent, objective without an accurate diagnosis, and Instrumented road to recovery is not possible and the determination of each of these works by utilizing rational principles. No rational design of actual knowledge of its purpose cannot be provided. Of human knowledge, that is certainly the truth may access certain doubts is condemned to invalidity. Never be without the help of axioms and rationalization spoke about proving it.

If we accept that the man is emotional, physical, intellectual, emotional and spiritual, then we must pay attention to one aspect of the spiritual dimension of human existence, unrelated to other dimensions, is not going to work and save. Spiritual man teaching a series of ontological - anthropological, which, according to certain ideas and knowledge of, the teachings of their cognitive task given that it is moral to say.

So addressing the question of purpose and meaning of life, the three areas are intertwined and affect each other, must be considered: 1. cosmology and philosophy of life 2. Ethics 3. Psychology, positive psychology approach to why change knowledge and ethics as a basic infrastructure, the purpose of excellence, impressive. According to Allport (1978), the most important task of a psychologist and a psychological study of the human personality, religion, human and religious personality of man.

Bill Grieve and Deluty in a research about the beliefs of clinicians and consultants conclude thatm any psychologists have specific world, consisting of certain religious beliefs, that these personal beliefs are important for them and used them for mental health (1998, p. 346).

The truth of beliefs and values in laboratory and experimental, is not assessable. Because of epistemic method is rational and self-affirmation and negation of science, no, positively and negatively to do with not the ultimate cause. In this regard, Seligman (2013) argues that to understand the relationship between ethics and psychology not succeed. Lyle believes that "from the perspective of religious and spiritual, understand that a human being? What is to be alone with the psychological contract cannot be understood" (1995, p. 80). While in the words of Yang, the lack of dignity and purpose and rely on psychology is clearly visible. Yang defines the relationship between religion and God: "Religion is man's relationship with the most wonderful or the most capable" value "or positive, or negative. . . . The psychological fact that in man, the greatest power to create, as God appears "(Azerbaijani, Mousavi Asl, 2011, p. 65).

Rickman unique knowledge of experimental methods have been criticized and relying on laboratory experience as observer only knows that despite the openness, the keyhole appears to the cast (Azerbaijani, Mousavi, 2011). "Unfortunately, the language of spirituality concepts such as: the sacred, God, freedom, patience, suffering, faith, secrets, limitation, sacrifice, mercy, and the changes are not known to psychologists. However, a bridge between the ideology, methods, and values, spirituality and worldview, procedures, and values, psychological, could be much to gain. "(Snyder, Lopez, 2002, p 656).

So, despite the fact that spirituality and belief in a higher purpose is essential process in the field of positive psychology, but it must be said, positive psychology by just rely on psychological principles and positivist methodology, cannot present a comprehensive and detailed account of the higher purpose in the path of prosperity of human truth.

\section{Discussion}

Here is an important question that should be answered reasonably and wisely is whether type, features and superior target detection is not effective to increase the prosperity and well-being and real safety of people? Is the knowledge of the highest and best purpose and meaning of life is necessary? If so, is pure science, positivist methods, existential philosophy, and fundamentally, oozing human reason able to introducing this transcendence creature? These are the questions that necessarily positive psychology in the process of their development, should be dealt with, and express knowledgeable and clear response. The answer certainly cannot presented without the attention and help of ontology domain and ethics. 


\section{Conclusion}

1. Islamic texts is almost overlap with positive psychology in define spirituality as a goal of sublime and superior performance, but in the principles and examples have major differences with each other.

2. The goal that is mentioned in intention would be a spiritual, sacred, transcendent, absolute object and has all the perfections and trusting relationship and faith in life, while the meaning of goal in Positive Psychology is any of the material and spiritual goal that superior than performance.

3. Sustainable peace, heart peace and unparalleled flexibility are unique consequences of a belief in the true intention. Despite the abundance and diversity, the non-distinguished goals in spirituality in positive psychology that its impact weren't overall and defined, and it is only achieved on temporary moments of sensory or mystical experience and will continue to have a limited radius.

4. Dealing with the purpose and meaning of life, the three areas are intertwined and affect each other, ontology, ethics and psychology should be noticed by positive psychologist. That's why in evolutionary process positive psychology, with special attention to ethics and knowledge area as the basis and infrastructure of the excellence goal, clear and knowledgeable answer should be given to the fundamental questions of human being.

5. Islam with the help of divine revelation has given an excellent, real and compelling response to the most fundamental questions and deepest needs of human being. According to which, using good capacity of positive psychology and spirituality of Islamic practices, we can give purpose and excellent to human in modern life, and tastes the real peace to him/her.

\section{References}

Quran

Nahjolbalaghe (2008). Translated by Mohammad Dashti, Tehran: GolGasht Publication. Ibn Tavos, Ali ibn Musa (1969). Fahiri Zanjani, Ahmad, Tehran: Jahan.

Ahmadi Faqih, Mohammad Hassan (1996). Intention: guidance, Tehran, publishing and research institute of Zekr.

Azerbaijani, Masoud and Mousavi Asl, Seyed Mahmood (2011). Psychology of Religion, Qom: Institute of Science.

Popkin, Richard, sterols, Arom (third edition). General philosophy, Mostafavi, Seyed Jala Aldin, Tehran: Hekmat Publications.

Tamimi Amadi, Abdul Wahid ibn Mohammad (1410 AH). Tricked og governance and pearls f words, Qom: Islamic Library.

Javadi Amoli, Abdollah. (2010). Tasnim, Volume 10th, Qom, the center of Isra printing.

Horr Ameli, Mohammed Ibn Hassan (1414 AH). Means of Shia, Qom: Al Bayt al Lahya' Altras.

Horr Ameli, Mohammed Ibn Hassan (2001). Self-fight Means of Shia, Afrasyabi Nahavandi, Ali, Qom: Nahavandi

Helli, Hassan Ibn Yusuf Ibn Motahar (2000). Nahj-ul-Haq and discovering the truth, Kohansal, Alireza, Mashhad: Ashura

Helli, Hassan Ibn Yusuf Ibn Motahar (1414). Jurists Biograghy, Qom: al-Bayt Institute.

Dehkhoda, Iraj. (1998). Dehkhoda dictionary, Tehran, Tehran University: Institute of dictionaries.

Seligman, Martin E. P. (2013). Shokofayi, Kamkar, Amir, Hozhbrian, Sakineh, Tehran Ravan publication.

Tabatabai, Seyed Mohammad Hossein (1417 AH). Almizan in Interpretation of Quran, Qom, Islamic Publications Office.

Tosi, Abu Jaafar, Mohammad Ibn Hassan (1407). Refinement of Laws, Tehran: Islamic library.

Ameli, Seyed javad Ibn Mohammad Hosseini (1419). Key of goodness in description of jurist rules, Qom, Islamic publishing office of the Society of Seminary Teachers of Qom.

Ameli, Mohammad Ibn Maki (1419). Shia mention in Sharia Laws, Qom: al-Bayt Institute.

Fakhreddine Razi, Abuabdallah Mohammed Ibn Umar (1420). Keys of the unseen, Beirut: Arab Daral hya alturat.

Frankl, Viktor (2011). Man's Search for Meaning, Salehian, Nehzat and Milani, Mahin, Tehran: Sadra publication.

Farahidi, Khali I Ibn Ahmad (1410). Al-In Book, Qom, Hejrat publication.

Carr, Alan (2012). Positive psychology, Pashasharifi, Hasan and Najafi Zand, Jafar, Tehran: Sokhan publication.

Kant, Immanuel (1990). Metaphysics of Ethics Foundation, Enayat, Hamid and Kaiser, Ali, Tehran: Khwarizmi publication.

Kallini, Mohammad Ibn Yaqub (1988 p). Al-Kafi, Tehran: Islamic library.

Luthans, Fred, ovule, J. Bruce. And M. Joseph, Caroline (2013). Psychological capital of organization, translated by Abdulrasol Jamshidian, Forouhar, Mohammad, Tehran Ayixh publication.

Majlesi, Mohammad baqher Mohammad Taghi (1999). Belief and unbelief (Bihar al-Anwar), Atarodi Ghouchani, Azizullah, Tehran: Atarodi publication.

Motahari, Morteza. (2000). Introduction to the Quran, Tehran, Sadra.

Mozaffar, Morteza. jurisprudence principles, Beirut: Media Institute.

Makarem Shirazi, Naser. (1998). Ethics in the Quran, first Volume, Qom, Imam Ali school.

West, William (2014). Psychotherapy and spirituality, Shahriar Shahidi and Sultanali Shirafkn, Tehran: Roshd.

Yazdi, Seyed Mostafa Mohaghegh Damad (1406). The rules of jurisprudence, Tehran: Publication Center of Islamic Sciences.

Johansson, Thor (2012). Religion and spirituality in psychotherapy and counseling, Farid Barati sadeh, Tehran: Roshd. 
Adler, A. (1956). The Individual Psychology of Alfred Adler. H. L. Ansbacher, \& R. R. Ansbacher (Eds. ). New York: Basic Books

Bilgrave, D. P. and Deluty, R. H. (1998). "Religious beliefs and therapeutic orientations of clinical and counseling psychologists", Journal for the Scientific study of Religion, 37 (2): 329-49.

Cowan, P. A. , Cowan, C. P. , \&Schulz, M. S. (1996). Thinking about risk and resilience in families. In E. M. Hetherington \& E. A. Blechman (Eds), Stress, coping, and resiliency in children and families (pp. 1-38). Mahwah, NJ: Erlbaum.

Doyle, D. (1992). Have we looked beyond the physical and psychosocial? Journal of Pain andm Symptom Management, 7, 302-311.

Gordon W. Allport, Basic considerations for a psychology of personality, (Yale University pres, U. S. A, Michigan, 1978). p. 93

Harter, S. (2002). Authenticity. In C. R. Snyder \&S. Lopez(Eds. ), Handbook of positive psychology (pp. 382-394). Oxford University Prss.

Hick, John (2000). The Religious Mean, (Oxford: Oneworld), pp. 269-286

Holaday,M. ,\& McPhearson, R. (1997). Resilience and sever burns. Journal of Counsel-ing and Development, 75,345-356.

Lopez. shane J. (2009). The encyclopedia of positive psychology, New York:. Blackwell Publishing. ISBN: 978-1-405-16125-1

Lyall, D. (1995). Counselling in the Pastoral and Spintual Context. Buckingham: Open University Press.

Mauritzen, J. (1988). Pastoral care for the dying and bereaved. Death Studies, 12, 111-122

Mosak, H. H. , \& Dreikurs, R. (1977). The life tasks III: The fifth life task. In H. H. Mosak (Ed. ) On Purpose: Callected papers. Chicago: Adler School of Professional Psychology. (Original work published 1967).

Pargament, K. I. (1999). The psychology of religion and spirituality? Yes and no. International Journal for the Psychology of Religion, (9), 3-16.

Parry, S. J and Jones, R. G. A. (1996). Beyond illusion in the psychotherapeutic enterprise, in G. Claxton (ed),Beyond Therapy: the Impact of Eastern Religions on Psychological Theory and Practice. Dorset: Prism

Rashid T. (2008). Positive psychotherapy. In: Lopez SJ, ed. Positive Psychology: Exploring the Best in People,Vol, 4. Westport, CT: Praeger Publishers,187-217

Ryff, C. D. , \& Singer, B. (1998). The role of purpose in life and personal growth in positive human health. In P. Wong \& P. Fry (Eds.), The human quest for meaning (pp. 213-236). Mahwah, NJ: Erlbaum

Salam, S. (2000). Foster trust through competence, honesty, and integrity. In E. Locke (Ed. ), Handbook of principle of organizational behavior (pp. 274-288). Oxford, UK: blackwell.

Shafranske, E. P. , \& Malony, H. N. (1996). Religion and the clinical practice of psychology: A case for inclusion. In E. P. Shafranske (Ed. ), Religion and the clinical practice of psychology (pp. 561-586). Washington, DC: American sychological Association

Snyder, C. R. Shane J. Lopez(2002). HandBook of positive psychology, UK: Oxford university Press.

Tart, C. T. \&Deikman, A. J. (1991). Mindfulness, spiritual seeking and psychotherapy, Journal of Transpersonal psychology, 23 (1): 29 52.

Twerski, A. J. (1998). Twerski on spirituality. Brooklyn, NY: Shaar Press.

Wulff, D. (1998). Psychology of religion: Classic and contemporary (2nd ed. ). New York: Wiley

Zinnbauer, B. J. , Pargament, K. I. , Cole, B. , Rye, M. S. , Butter, E. M. , Belavich, T. G. , Hipp, K. M. , Scott, A. B. , \& Kadar, J. L. (1997). Religion and spirituality: Unfuzzying the fuzzy. Journal for the Scientific Study of Religion, 36, 549-564 